ら，中央で放射線業務（との中には撮影，治療，核医学， 管理等の業務）を一括して行う組織に変わってきている わけです。この様な変化に対応していくためには，私達 放射線技師は現状をよく把握して，今後進むべき方向を 見い出さなければならないと思います。仕事の桩大と技 術の進歩についていくにはもつ之勉強して，地域住民の 健康増進に努めなければならないと思います。

\section{9. 尿路結石像の検討}

茅ケ崎书立病院放射線科

○北山、幹夫百瀨宏
福井達夫

体内に自然発生する胆石腎石あるいは石灰化像は，X 線発見以来, X線診断の対象とされてきた。胆石に比し て腎石についての発表は数少ない. そこでてのたび成分 により 3 種類の尿路結石を用いて，X線写真上の現出と の関係を研究し, 現出率の向上を試みた。 その結果, 結 石成分により不現出がある，現出向上のためには，体内 位置に対しては斜位撮影や時期をずらして摄影するなど 結石位犆の転換を試みる，撮影条件のうち管電圧は上限 を $80 \mathrm{kVp}$ とし, 結石像不現出の場合は, 低電圧撮影す 試みる、特浪酸を含む結石のように現出しにくいもの では，体厚に対して各々の現出可能電圧がある. 胃腸内 ガスについては, 薬剤使用や脘晹等の前処置を施行す ๖.

\section{0. 膝関節造影法（脛骨関節面の角度計測による 半月板示現)}

$$
\begin{aligned}
& \text { 横浜方立大学医学部附属病院 } \\
& \text { O天内 広 村山茂康 } \\
& \text { 鳴海 則雄 }
\end{aligned}
$$

[目的〕

半月板の正投影を得る為に次の方法をとった，1）脛 骨基準軸を脛骨粗面より遠位の脛骨前縁直線部としこの 基準軸と内・外脛骨関節面のなす角を单純写真加見出 す.2）X線人射角を正確にとる為，撮影台に固定した 基集平行板を作成し，そこ亿基準朝すなわち脛骨前縁直 線部を平行固定する－3）い汃なる風曲肢位も可能なよ う汇背腹方向へのX線水平入射を行った. 〔結論〕

1）脛骨関節面话は非常に侗人差があり計測撮影を必 要とする．2）計測基集軸は撮影時の基準軸である方が 現想的であり，脛骨前縁直線部が最屯遥当である３） 現在まで 150 例以上実施し結果は非常に良好である。4) X線入射は背腹方向が最も適当である.

11. 口腔外科領域における $X$ 線シネ撮影について
埼玉医科大学附属病院放射線科

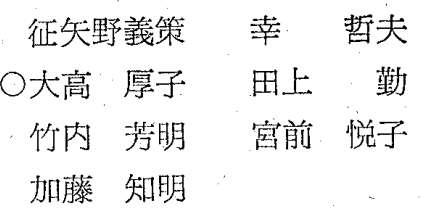

当院で，従来の遠隔操作式透視撮影装置（島津ZS-1 単相全波）を改良し，頡関節のシネ撮影を行った．当初 の使用説明では，管電圧 $120 \mathrm{kVp}$ ，管電流 $10 \mathrm{~mA}$ でシネ 撮影可能々あったが実際には，満足出来るフイルムは得 られなかった。 そとで次の 5 点の改良を加えた。(1)管電 流 5，10，20，30 mA 選択可能，(2)イメージズームの利 用，(3)付属カメラレンズ選択，(4)フイルム選択，(5)被曝 線量軽減法（フィルター, $5 \mathrm{nmPb}$ 板防護マスク）：以上 の事により水晶体被爆線量は約半分になり，鮮鋭度子増 し, 臨床価值（㖽関節腔の動態観察可能）のある物が得 られた．しかし，黑化度，被曝等の問題より.シネパル 久同期. 透視ビデオテープからの変換す必要であろう.

\section{2. 大腸の $\mathrm{X}$ 線検查法について}

国立東京第二病院放射線科

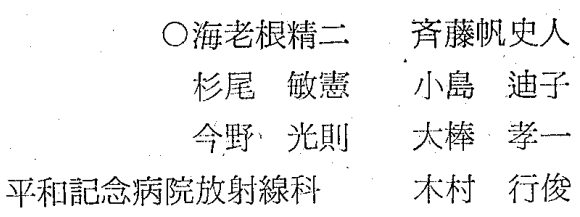

私たち放射線技師が大晹X線検査にあたり，どのよう な知識を必要とし，またどのような点に注意をしなけれ ばならないか，私達の経験から技師の立場でお犃をして 見たいと思います。胃X線竛断学の進歩沙早期癌をはじ め目ざましい進歩であるが大腸X線診断学は胃X線検查 亿比較し進歩の遅れは否定出来ない。しかし最近ではX 線装置の改良及び注腸器具の改良などで大腸検査む容易 に行うことが可能になってきたので，放射線技師む大晹 検查法についてのひと通りの知識がなければ，琴断価值 の高いX線写真像を医師に提供出来ないのでここに種々 の点について括をしてみたいと思います。

\section{3. 注腸検查用ダブルバルーンカテーテル}

東京医科大学病院

渡理 正英 ○沢村 光男 国府田幸雄

北九州沛立立戸烟病院

高根 需信 国下 善継

国立東京第二病院 海老根精二:

上尾総合中央病院

武山 秀正 広沢三三四

河井病院藤田良三 


\section{富士見病院 篠宮．勝利}

一般に広く使用されている注腸用カテーテルは種々あ るが満足すべき製品はない，検查時造影剤の流出，体位 の変换を行うとき老人または小児等において，肚門管か らカテーテルがはずれ，検查を一時中止するとと等であ った．そこで，我々は注腸用ダブル・バルーン，カテー テルの開発を行った. カテーテルは外肛閏括約筋を口側 と肛門側の両側から膨んだバルーンではさむ形式にし た.結果は満足すべきすのであった。

\section{4. 千葉県がんセンターにおける小腸検查の実際と 問題点}

$$
\text { 干葉県がんセンター放射線部 }
$$

永井 義衛

消化管の中で最も大切な部分は小腸であるにもかかわ らず，小腸のX線診断学は霄や大腸に比べもっとも遅れ て発展してきた。しかし最近潰瘍性病変を中心として小 腸の疾患が注目されだし検査の検討が望まれてきたので 過去 3 年間の小腸検查の実際亡問題点を導きだし改良へ の足がかりとして検討を試みた。

小腸検查には種々方法があるが主な方法としては経口 法が一番利用される。しかし機能的疾患にはよいが器質 的疾患には多くを望めない，そこでこれからは器質的疾 患にかかせない二重造影法をとり入れたゾンデ使用の小 晹造影法を主流に，又他方では技師でも可能な小腸二重 造影法を試験中であるので第二報で報告できるものと思 う.

\section{5. 画像の視覚評価の再検討（視覚の法則の応用）}

日本医科大学附属病院放射線科

O川村 義彦 鈴木 洵
石田 勝哉

目で見て画像を評価する主観的方法をこりあげ検討を した. 方法は放射線技師の画像評価過程を考え，乙の中 の大脳視覚領域の特街抽出について検討した。 そしてゲ シュタルトの法則, 及び視覚の法則の再認識から，視覚 評価の何らかの糸口を見いだすととを試みた。実験には $\mathrm{Al}, \mathrm{Cu}, \mathrm{Pb}$ 板を打ち拔き，意識的に形を作ったパタ一 ンと, 撮影して出来た写真の視覚の法則からの像認識と の対比をした. その結果，視覚の法則を表面に引き出し， 画像形成の違いをもとめることにより，今までの評洒の あいまいさにある程度の客钼性が得られる.さらに今後 視覚の法則からみたX線像の解折を行い，検討を扣えて いく予定である。

\section{6. 断層理論の新しい試み（第 3 報） 空間周波数特性の三次元への応用}

$$
\text { 千葉罧がんセンター 毛利 快晴 }
$$

多軌道断層像の解析にジーメンススタ一を用いる方法 は前 2 回にわたり発表した。との方法は，スタ一を直接 断層撮影してフィルム上のスター像を解析したのである が，今回は模型光学断層系を用いて，いろいろな軌道を 幾何光学的に解析し, 実際のスタ一㒋㬝像之の比較を試 み、これらが良い一致を示したので，スタ一の断層系の 解析への有用性がわかったのでここで発表する。

模型光学系としては，各軌道相当のスリットを作製し スターをこのスリット光線により半透明スクリーン上に 投影し，乙の像をカメラで撮影して解析した．との場合 スターの位置のスクリーンからの離れを断層中心面から のずれは今までの厚さのその半分之考えられる.

\section{7. 多軌道断層の実態について}

長野赤十学病院

樃沢 信男永田”英雄

無作為に撰出した全国58施設にアンケートを依頼し， 多軌道断層装置に関して18施設から回答があり, 設置さ れていない施設は21施設，末回答19施設という結果でし た。アンケートは, 頭部, 耳鼻科領域, 颈椎, 胸腰椎, 胸骨, 顎関節, 下顎骨について軌道, 撮影法, 増感紙, その他補助具等について調査しました。

幾何学的不鮮鋭度が断層像に大きな影響をあたえるた め小焦点断層が行われる傾向にあり，軌道の撰択は使用 する軌道の障輩陰影のとらえ方が十分なされててれれ゙， 軌道の撰択にあまりとらわれる必要はなく，要はいかに 多くの診断情報を提供しうるかであるが, 解剖学的知識 に基づく, 振り角, 軌道の撰択が要求される。

\section{8. ポリトームU断層撮影装置の選択的限定曝射への 改造之診断(特に縦隔部) 効果にういて \\ 関東屚信病院放射線科}

金場 敏䨓 柴田英三郎

多軌道断層撮影装置における，円軌道の胸部断層撮影 （特に縦隔部）において，選択的限定曝射の有用性は， 先に発表されており，国産の断層撮影装置ではすでに応 用されているあのである.しかし，当科のポリトームU 亿は選択的限定曝射の機能が組み込まれておらず，“その 便法として最近まで,リスホルムブレンデを使用して，全 円周曝射をフイルム面上で限定曝射とし，縦䧣部の断譄 撮影に効果を上げてきたが, この方法は, 被曝線量, 画質 因子等の多くの問題を有する為，ポリトーム内の電気回 路を改造して選択的限定曝射を行えるようになり良い結 果を得，ルーチン撮影しして使用しているので報告する.

\section{9. 傾斜截断面の断層撮影 (Princeps 60 による}

